\title{
Correction: Trends in sugar supply and consumption in Australia: is there an Australian Paradox?
}

Wavne Rikkers, David Lawrence, Katherine Hafekost ${ }^{*}$, Francis Mitrou and Stephen R Zubrick

This correction article relates to the response by Alan Barclay and Jennie Brand-Miller that was published as part of a research article [1] authored by Rikkers et al. During the publication process, errors were introduced into the formatting which affected the response only and caused the paragraphs to appear in the incorrect order. The research article reported by Rikkers et al. was not affected. A corrected version of the response has subsequently been published as a correspondence article [2]. BioMed Central apologize for any inconvenience caused.

Received: 27 November 2013 Accepted: 29 November 2013

Published: 5 December 2013

\section{References}

1. Rikkers W, Lawrence D, Hafekost K, Mitrou F, Zubrick SR: Trends in sugar supply and consumption in Australia: is there an Australian Paradox? BMC Public Health 2013, 13:668.

2. Barclay AW, Brand-Miller J: Trends in sugar supply and consumption in Australia: is there an Australian Paradox? BMC Public Health 2013, 13:898. consumption in Australia: is there an Australian Paradox? BMC Public Health 2013 13:1134.

\footnotetext{
*Correspondence: khafekost@ichr.uwa.edu.au

Telethon Institute for Child Health Research, Centre for Child Health

Research, The University of Western Australia, PO Box 855, West Perth WA 6872, Australia
}

\section{Submit your next manuscript to BioMed Central and take full advantage of:}

- Convenient online submission

- Thorough peer review

- No space constraints or color figure charges

- Immediate publication on acceptance

- Inclusion in PubMed, CAS, Scopus and Google Scholar

- Research which is freely available for redistribution

Submit your manuscript at

www.biomedcentral.com/submit

( Biomed Central

\section{Biomed Central}

(c) 2013 Rikkers et al.; licensee BioMed Central Ltd. This is an Open Access article distributed under the terms of the Creative Commons Attribution License (http://creativecommons.org/licenses/by/2.0), which permits unrestricted use, distribution, and reproduction in any medium, provided the original work is properly cited. The Creative Commons Public Domain Dedication waiver (http://creativecommons.org/publicdomain/zero/1.0/) applies to the data made available in this article, unless otherwise stated. 